\title{
Safety, tolerability and pharmacokinetics of the fibroblast growth factor receptor inhibitor AZD4547 in Japanese patients with advanced solid tumours: a Phase I study
}

\author{
Hideo Saka $^{1}$ - Chiyoe Kitagawa ${ }^{1}$ - Yoshihito Kogure ${ }^{1}$ - Yasuo Takahashi ${ }^{2}$. \\ Koshi Fujikawa $^{2}$. Tamotsu Sagawa ${ }^{2}$ - Satoru Iwasa ${ }^{3}$ - Naoki Takahashi ${ }^{3}$. Taro Fukao ${ }^{4}$. \\ Catherine Tchinou ${ }^{5}$ Dónal Landers ${ }^{5}$ - Yasuhide Yamada ${ }^{3}$
}

Received: 28 September 2016 / Accepted: 7 December 2016/Published online: 10 January 2017

(C) The Author(s) 2017. This article is published with open access at Springerlink.com

Summary Background AZD4547 is a potent, oral, highly selective fibroblast growth factor receptor (FGFR) inhibitor in clinical development for treating tumours with a range of FGFR aberrations, including FGFR mutations, amplifications and fusions. Methods This open-label, Phase I, multicentre study (NCT01213160) evaluated the safety, pharmacokinetics, and preliminary antitumour efficacy (RECIST v1.1) of AZD4547 monotherapy in Japanese patients with advanced solid tumours. Part A was a dose-escalation part; Part B was a dose-expansion part in patients with FGFR-amplified tumours, confirmed by fluorescence in situ hybridization. Results Thirty patients enrolled in Part A (dose range: $40 \mathrm{mg}$ twice daily [bid] to $120 \mathrm{mg}$ bid; $160 \mathrm{mg}$ once daily [qd]), four in Part B ( $80 \mathrm{mg}$ bid). No dose-limiting toxicities were observed and maximum tolerated dose was not determined. Most common adverse events (AEs; any grade) were: dysgeusia (50\% of patients); stomatitis $(41 \%)$; diarrhoea (38\%); hyperphosphataemia (38\%); dry mouth (35\%). Common grade $\geq 3$ AEs were nausea (12\% of patients) and neutropenia (9\%). No complete or partial responses were observed: $21 / 30$ patients had stable disease $\geq 4$ weeks in Part A, and 1/4 patients had stable disease

Hideo Saka

saka@med.nagoya-u.ac.jp

1 Department of Medical Oncology, Nagoya Medical Center, 4-1-1 Sannomaru, Naka-ku, Nagoya, Aichi 460-0001, Japan

2 Department of Gastroenterological Medicine, Hokkaido Cancer Center, Hokkaido, Japan

3 Department of Medical Oncology, Gastrointestinal Medical Oncology Division, National Cancer Center Hospital, Tokyo, Japan

$4 \quad \mathrm{R} \& \mathrm{D}$, AstraZeneca KK, Osaka, Japan

5 AstraZeneca, Macclesfield, UK $\geq 10$ weeks in Part B. Following single and multiple dosing, absorption rate appeared moderate; peak plasma concentrations generally occurred 3-4 h post-dose, then declined biphasically with terminal half-life $\sim 30 \mathrm{~h}$. Steady state was reached by day 8 . Compared with single dosing, plasma concentrations were, on average, 2.4- and 3.3- to 5.4-fold higher after qd and bid dosing, respectively. Conclusions AZD4547 was well tolerated in Japanese patients, with best response of stable disease $\geq 4$ weeks.

Keywords AZD4547 · FGFR · Japanese · Phase I · Safety · Pharmacokinetics

\section{Introduction}

Fibroblast growth factor receptors (FGFRs) are transmembrane receptor tyrosine kinases with varied biological roles in regulating angiogenesis, cell proliferation, differentiation, migration and survival. Altered FGFR signalling has the potential to drive mitogenic, invasive, anti-apoptotic and pro-angiogenic cells and has been increasingly implicated in a range of solid tumour types, including breast cancer (BC), high-grade bladder cancer, non-small-cell lung cancer (NSCLC) and gastric cancer (GC), as well as haematological malignancies. Of the five known FGFRs found in humans, FGFR1-4 are characterized by extracellular immunoglobulin-like and intracellular tyrosine kinase domains, whereas the atypical FGFR5 (also known as fibroblast growth factor receptor-like 1) lacks the cytoplasmic tyrosine kinase domain; consequently, its role is less understood. There are several mechanisms underlying the misregulation of FGFRs in neoplastic disease, including activating mutations in FGFRs [1, 2], FGFR gene amplification [2-6], FGFR chromosomal translocations [7-9], alternative splicing of FGFRs [10], 
and altered autocrine and paracrine signalling at FGFRs via FGF [2].

AZD4547 is a potent, oral, highly selective inhibitor of FGFR1-3 with proven antitumour properties from preclinical studies [11-15], including work in FGFR2-amplified GC xenografts that demonstrated complete and prolonged tumour regression in several AZD4547-treated animals [12]. An initial Phase I study in a Western population indicated that AZD4547 monotherapy has an acceptable safety profile in patients with several tumour types (NCT00979134). During this study, a partial response (PR) was observed following AZD4547 treatment in a patient with FGFR1-amplified squamous NSCLC. Stable disease was experienced by $4 / 21$ additional patients $(19.0 \%)$, three of whom had confirmed FGFR amplification status (squamous NSCLC, $n=1$; bladder cancer, $n=1$; BC, $n=1$ ) [16]. These data suggest a potential association between FGFR amplification status and clinical benefit with AZD4547 therapy.

It is thought that FGFRs mediate angiogenesis through their synergistic role with vascular endothelial growth factor receptors (VEGFRs). The success of bevacizumab, a monoclonal antibody that became the first approved anti-VEGF therapy, has given rise to several anti-angiogenic therapies, most notably, a group of oral tyrosine kinase inhibitors (TKIs) targeting VEGFR. Although these drugs, which include sunitinib [17, 18], sorafenib [19-22], pazopanib [23, 24] and cediranib [25-28], have demonstrated promising results in patients with advanced cancer, resistance generally develops following an initial clinical response, and patients experience relapse. Preclinical data have demonstrated that tumours with resistance to anti-VEGF therapies can overexpress FGFs, and there is clinical evidence indicating that disease progression following bevacizumab treatment is preceded by an increase in levels of basic FGF (bFGF) [29, 30]. Elevated bFGF levels were also significantly associated with shorter overall survival in cediranib-treated patients $[30,31]$. These data suggest that inhibition of FGFRs, together with direct antitumour activity, may play a role in preventing resistance to anti-angiogenic drugs [29].

This Phase I study (NCT01213160) was designed to evaluate the safety and tolerability, appropriate dosing, pharmacokinetic (PK) profile, and preliminary antitumour effects of AZD4547 when administered in Japanese patients with advanced solid malignancies.

\section{Methods}

\section{Patients}

Eligible patients had confirmed solid malignancies for which standard therapies did not exist or were no longer effective, a World Health Organization (WHO) performance status of 0
1 , and a life expectancy of at least 12 weeks. Previous preclinical data have revealed pharmacodynamic effects on cartilage and growing bones following treatment with another FGFR inhibitor [32]. In order to ensure that maturation of the skeleton is complete upon entry into this study, eligible patients must be aged $\geq 25$ years. Exclusion criteria included: any chemotherapy, immunotherapy, or anticancer agents $\leq 3$ weeks prior to study entry; major surgery or radiotherapy $\leq 4$ weeks prior to study entry; nitrosourea or mitomycin $\mathrm{C} \leq 6$ weeks prior to study entry; any unresolved toxicities from previous treatments exceeding Common Terminology Criteria for Adverse Events (CTCAE) grade 1 (excluding alopecia). Specific cardiac- and ophthalmologically related exclusion criteria included: clinically important electrocardiogram (ECG) abnormalities; QT interval $\geq 470 \mathrm{~ms}$; history or evidence of retinal pigmented epithelial detachment; history or evidence of age-related macular degeneration. Other exclusion criteria included: spinal cord compression; brain metastases; severe or uncontrolled systemic disease; inadequate bone marrow reserves or organ function. The study was approved by the independent ethics committee, research ethics board or institutional review board at each centre and complied with the International Conference on Harmonisation's Harmonised Tripartite Guidelines for Good Clinical Practice, the Declaration of Helsinki and local laws. All patients provided written informed consent.

\section{Study design}

This Phase I, open-label, Japanese, multicentre study was conducted in two parts (Fig. 1). Part A was a dose-escalation

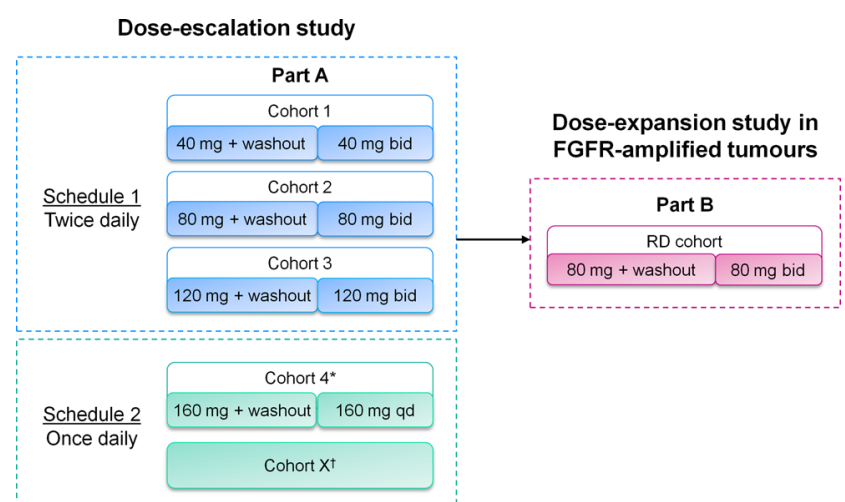

Fig. 1 AZD4547 Japanese Phase I study design. Part A was a doseescalation study with a 5- to 10-day washout period followed by bid dosing. Part B was a dose-escalation study in patients with FGFRamplified tumours with an RP2D of $80 \mathrm{mg}$ bid. *Cohort 4 dose was based on PK modelling data and was consistent with the latest tolerated exposures from AZD4547 bid dosing in Western patients [16], as well as emerging safety data from Japanese patients (this study); ${ }^{\dagger}$ In schedule 2, it was planned that dose assessment could extend over multiple cohorts; however, no cohorts exceeded the $160 \mathrm{mg}$ qd dosing level due to emerging data from the study in Western patients and a decision from the clinical project team. RP2D, recommended Phase II dose 
phase. Single oral dosing ( $40 \mathrm{mg}$; $80 \mathrm{mg} ; 120 \mathrm{mg}$ ) was followed by a 1 -week washout period. Multiple oral dosing was delivered in 21-day cycles according to two treatment schedules: schedule one (40 mg twice daily [bid]; $80 \mathrm{mg}$ bid; $120 \mathrm{mg}$ bid) and schedule two (160 mg once daily [qd]). Part B was an expansion phase that evaluated a recommended dose (RD) of $80 \mathrm{mg}$ bid in FGFR-amplified tumours. FGFR amplification was determined by central fluorescence in situ hybridization (FISH) testing of archival tumour samples. This $\mathrm{RD}$ was determined using both emerging data from Part A and existing data from the study in Western patients (NCT00979134) [16].

A 'rolling six' design was used, with a minimum of three evaluable patients per cohort [33]. If one patient experienced a dose-limiting toxicity (DLT), additional patients were enrolled up to a maximum of six evaluable patients. DLTs were evaluated during the washout period and the first 21-day treatment schedule. These were defined as any toxicity not attributable to the disease under investigation, including haematological toxicity of CTCAE grade $\geq 4$, non-haematological toxicity of CTCAE grade $\geq 3$, and any other toxicity that was clinically significant, did not respond to supportive care and resulted in discontinuation of dosing. If two or more evaluable patients experienced a DLT, this dosing level was considered as nontolerable. It was planned that the maximum tolerated dose (MTD) would be defined either as the dosing level below the non-tolerated dose or such that a dose between the nontolerated dose and the last tolerated dose may be investigated. Patients who tolerated AZD4547 treatment and received clinical benefit were permitted to continue treatment until they experienced progressive disease or withdrew consent.

\section{Study objectives}

The primary objective of this study was to evaluate the safety and tolerability of oral AZD4547 in Japanese patients with advanced solid malignancies. Secondary objectives included defining the MTD and/or a tolerable RD, characterizing the PK properties following both single and multiple dosing of AZD4547, and exploring the preliminary antitumour activity of AZD4547.

\section{Assessments}

\section{Safety and tolerability}

Safety and tolerability were assessed during study treatment and until 28 days after the final dose. Adverse events (AEs) were evaluated according to CTCAE (version 4.0), and dose interruptions and reductions were recorded. Laboratory findings and vital signs were analysed. Cardiac monitoring (echocardiogram [ECHO] and ECG) and ophthalmic assessments were also conducted.

\section{Pharmacokinetic assessments}

Blood samples for PK analysis were collected pre-dose and at defined intervals up to $96 \mathrm{~h}$ following single dosing, and up to $24 \mathrm{~h}$ following multiple dosing. Urine samples were also collected during the $24 \mathrm{~h}$ after multiple dosing in order to perform urinary PK assessments. For multiple dosing, the $80 \mathrm{mg}$ bid dosing level was evaluated using combined data from patients in both Part A and Part B, as FGFR amplification status was unlikely to have a significant impact on PK. Concentrations of AZD4547 in human plasma and urine were determined using a validated high-performance liquid chromatography-tandem mass spectrometry method at PRA International (Assen, The Netherlands). PK parameters were analysed by standard non-compartmental methods using WinNonlin software (Pharsight Corporation, Mountain View, CA, USA).

\section{Efficacy}

Tumour assessments were performed according to Response Evaluation Criteria in Solid Tumors version 1.1 (RECIST v1.1) at baseline, on day 21 of the first treatment cycle, then every 6 weeks after the start of treatment for 12 weeks, and thereafter every 12 weeks ( \pm 1 week) until discontinuation of study treatment or withdrawal of consent.

\section{Statistics}

No formal hypothesis-led statistical analysis was performed. Safety, tolerability, PK data and efficacy were summarized using descriptive statistics. Analysis sets for safety and efficacy contained all patients who received $\geq 1$ dose of AZD4547. PK analysis included all patients who provided blood samples.

\section{Results}

\section{Patient characteristics}

Between 5 November 2010 and 22 November 2012, 30 Japanese patients were enrolled in Part A of this study (male, $n=16$; female, $n=14$ ) and four in Part B (male, $n=3$; female, $n=1$ ). All patients received at least one dose of AZD4547 and were evaluable for safety, PK, and efficacy analyses. A summary of patient characteristics is given in Table 1 . The mean age of patients was 62.3 years (range 30-78 years) in Part A and 70.8 years (range $64-76$ years) in Part B. The major primary tumour locations were lung (33.3\% in Part A; $25.0 \%$ in Part B), breast $(16.7 \% ; 25.0 \%)$, and stomach $(13.3 \% ; 50.0 \%)$. The majority of patients $(93.3 \%)$ in Part A and all patients in Part B had metastatic disease, with the respiratory system and lymph nodes as the most commonly reported disease sites. At 
Table 1 Patient demographics and baseline characteristics

AZD4547 dose

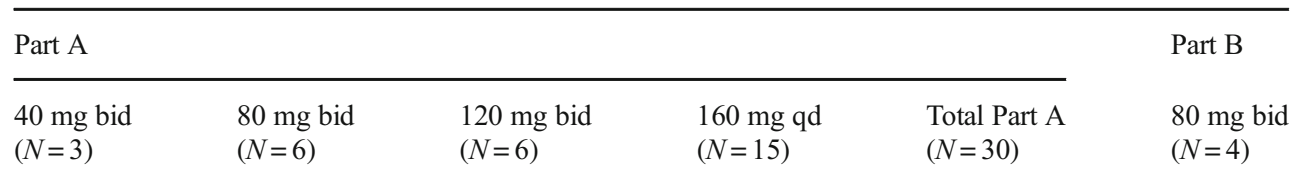

\begin{tabular}{|c|c|c|c|c|c|c|}
\hline \multicolumn{7}{|l|}{ Sex, n $(\%)$} \\
\hline Female & $1(33.3)$ & $4(66.7)$ & $2(66.7)$ & $7(46.7)$ & $14(46.7)$ & $1(25.0)$ \\
\hline Male & $2(66.7)$ & $2(33.3)$ & $4(33.3)$ & $8(53.3)$ & $16(53.5)$ & $3(75.0)$ \\
\hline Median age, years & 49 & 63.5 & 61.5 & 66.0 & 63.5 & 71.5 \\
\hline (range) & $(41-73)$ & $(30-76)$ & $(47-76)$ & $(51-78)$ & $(30-78)$ & $(64-76)$ \\
\hline \multicolumn{7}{|l|}{ WHO performance status, n (\%) } \\
\hline 0 & $3(100)$ & $5(83.3)$ & $3(50.0)$ & $7(46.7)$ & $18(60.0)$ & $2(50.0)$ \\
\hline 1 & $0(0)$ & $1(16.7)$ & $3(50.0)$ & $8(53.3)$ & $12(40.0)$ & $2(50.0)$ \\
\hline \multicolumn{7}{|l|}{ Local/metastatic sites, n (\%) } \\
\hline Local only & $0(0)$ & $0(0)$ & $1(16.7)$ & $1(6.7)$ & $2(6.7)$ & 0 \\
\hline Local $/$ metastatic & $3(100)$ & $6(100)$ & $5(83.3)$ & $14(93.3)$ & $28(93.3)$ & $4(100)$ \\
\hline \multicolumn{7}{|c|}{ Common primary tumour types, $\mathrm{n}(\%)$} \\
\hline Bile duct & $0(0)$ & $0(0)$ & $0(0)$ & $1(6.7)$ & $1(3.3)$ & $0(0)$ \\
\hline Bladder & $0(0)$ & $0(0)$ & $0(0)$ & $1(6.7)$ & $1(3.3)$ & $0(0)$ \\
\hline Breast & $0(0)$ & $4(66.7)$ & $0(0)$ & $1(6.7)$ & $5(16.7)$ & $1(25.0)$ \\
\hline Caecum & $1(33.3)$ & $0(0)$ & $0(0)$ & $0(0)$ & $1(3.3)$ & $0(0)$ \\
\hline Colon & $1(33.3)$ & $1(16.7)$ & $0(0)$ & $0(0)$ & $2(6.7)$ & $0(0)$ \\
\hline Colorectal & $0(0)$ & $0(0)$ & $0(0)$ & $1(6.7)$ & $1(3.3)$ & $0(0)$ \\
\hline Lung & $0(0)$ & $1(16.7)$ & $3(50.0)$ & $6(40.0)$ & $10(33.3)$ & $1(25.0)$ \\
\hline Oesophagus & $0(0)$ & $0(0)$ & $0(0)$ & $1(6.7)$ & $1(3.3)$ & $0(0)$ \\
\hline Pancreas & $0(0)$ & $0(0)$ & $1(16.7)$ & $0(0)$ & $1(3.3)$ & $0(0)$ \\
\hline Rectal & $0(0)$ & $0(0)$ & $0(0)$ & $1(6.7)$ & $1(3.3)$ & $0(0)$ \\
\hline Stomach & $0(0)$ & $0(0)$ & $1(16.7)$ & $3(20.0)$ & $4(13.3)$ & $2(50.0)$ \\
\hline Thymus & $1(33.3)$ & $0(0)$ & $0(0)$ & $0(0)$ & $1(3.3)$ & $0(0)$ \\
\hline Urachus & $0(0)$ & $0(0)$ & $1(16.7)$ & $0(0)$ & $1(3.3)$ & $0(0)$ \\
\hline \multicolumn{7}{|l|}{ Prior therapy, n (\%) } \\
\hline Chemotherapy & $2(66.7)$ & $6(100)$ & $6(100)$ & $15(100)$ & $29(96.7)$ & $4(100)$ \\
\hline $\begin{array}{l}\text { Other systemic } \\
\text { anticancer therapy }\end{array}$ & $2(66.7)$ & $2(33.3)$ & $1(16.7)$ & $6(40.0)$ & $11(36.7)$ & $1(25.0)$ \\
\hline Radiotherapy & $3(100)$ & $6(100)$ & $6(100)$ & $15(100)$ & $30(100)$ & $4(100)$ \\
\hline Hormonal/immunotherapy & $0(0)$ & $1(16.7)$ & $0(0)$ & $2(13.3)$ & $3(33.3)$ & $0(0)$ \\
\hline
\end{tabular}

entry into this study, most patients had received prior radiotherapy (96.7\% in Part A; 100\% in Part B) and all had received previous chemotherapy, with $26.7 \%$ and $25.0 \%$ of patients having received $\geq 3$ lines of previous chemotherapy in Parts $\mathrm{A}$ and $\mathrm{B}$, respectively.

\section{Safety and tolerability}

\section{Dose escalations}

During the dose-escalation phase in Part A, AZD4547 dosing was escalated in three cohorts in schedule one $(40 \mathrm{mg}$ bid;
$60 \mathrm{mg}$ bid; $120 \mathrm{mg}$ bid). Based on the emerging safety profile, the safety review committee authorized the initiation of schedule two, a once-daily dose, in a fourth cohort (160 mg qd). However, based on emerging data from the study in Western patients [16] and a decision from the clinical project team, the qd dose regimen was not escalated to $240 \mathrm{mg}$.

No DLTs were observed across any of the four cohorts examined and given the decision not to titrate beyond the once-daily schedule of $160 \mathrm{mg}$ qd, the MTD was not determined for Japanese patients in this study. Instead, the recommended dose of $80 \mathrm{mg}$ bid for assessment in Part B was determined based on safety data from Part A of this study 
alongside the data in Western patients [16]. No DLTs were observed with the RD of $80 \mathrm{mg}$ bid in Part B.

All patients had discontinued the study by the data cut-off date (16 August 2013). The most common reasons for discontinuation in Part A were disease progression in 14/30 patients (46.7\%), AEs in $9 / 30$ patients $(30.0 \%$; $80 \mathrm{mg}$ bid, $n=3$; $160 \mathrm{mg} \mathrm{qd}, n=6)$, and death in $1 / 4$ patients $(25.0 \% ; 160 \mathrm{mg}$ qd). All patients ( $80 \mathrm{mg}$ bid, $n=4$ ) in Part B discontinued AZD4547 following disease progression.

\section{Summary of AEs}

Overall, 32/34 patients (94.1\%) experienced at least one AE following AZD4547 treatment (Table 2); the AEs of 30/34 patients $(88.2 \%)$ were considered by the investigator to be causally related to AZD4547. The most frequently reported AEs $(\geq 20 \%)$ in Part A were dysgeusia in 14 patients (46.7\%), diarrhoea in $12(40.0 \%)$, stomatitis in $12(40.0 \%)$, hyperphosphataemia in $11(36.7 \%)$, dry mouth in 10 (33.3\%), dry skin in nine $(30.0 \%)$, nausea in eight $(26.7 \%)$, detachment of retinal pigment epithelium in seven $(23.3 \%)$, vomiting in six $(20.0 \%)$, malaise in six $(20.0 \%)$, nail discolouration in six (20.0\%), and pruritus in six $(20.0 \%)$. The most common AEs $(\geq 50 \%)$ in Part B were dysgeusia in three patients $(75.0 \%)$ and stomatitis, hyperphosphataemia, dry mouth, nausea, and decreased appetite, which were all present in two patients each $(50.0 \%)$. Three patients (10.0\%) experienced an AE of CTCAE grade $\geq 3$ in Part A ( $80 \mathrm{mg}$ bid); these were judged to be causally related to the study treatment in one patient (3.3\%). Three patients (75.0\%) experienced an $\mathrm{AE}$ of CTCAE grade $\geq 3$ in Part B; however, these AEs were not deemed to be treatment related. Overall $(N=34)$, the most common CTCAE grade $\geq 3$ AEs were neutropenia in three patients (8.8\%), nausea in two (5.8\%), and decreased appetite

Table 2 Summary of AEs occurring in $\geq 20 \%$ of all patients, AEs of grade $\geq 3$ occurring in $\geq 5 \%$ of all patients, and SAEs for each cohort

\begin{tabular}{|c|c|c|c|c|c|c|}
\hline & \multicolumn{6}{|c|}{ AZD4547 dose } \\
\hline & \multicolumn{5}{|l|}{ Part A } & \multirow{2}{*}{$\begin{array}{l}\text { Part B } \\
80 \mathrm{mg} \text { bid } \\
(N=4)\end{array}$} \\
\hline & $\begin{array}{l}40 \mathrm{mg} \text { bid } \\
(N=3)\end{array}$ & $\begin{array}{l}80 \mathrm{mg} \text { bid } \\
(N=6)\end{array}$ & $\begin{array}{l}120 \mathrm{mg} \text { bid } \\
(N=6)\end{array}$ & $\begin{array}{l}160 \mathrm{mg} \mathrm{qd} \\
(N=15)\end{array}$ & $\begin{array}{l}\text { Total } \\
\text { Part A }(N=30)\end{array}$ & \\
\hline Patients with AE of any grade, $\mathrm{n}(\%)$ & $3(100)$ & $6(100)$ & $6(100)$ & $14(93.3)$ & $29(97.6)$ & $4(100)$ \\
\hline Dysgeusia & $0(0)$ & $2(33.3)$ & $5(83.3)$ & $7(50.0)$ & $14(46.7)$ & $3(75.0)$ \\
\hline Diarrhoea & $0(0)$ & $2(33.3)$ & $5(83.3)$ & $5(33.3)$ & $12(40.0)$ & $1(25.0)$ \\
\hline Stomatitis & $1(33.3)$ & $4(66.7)$ & $4(66.7)$ & $3(20.0)$ & $12(40.0)$ & $2(50.0)$ \\
\hline Hyperphosphataemia & $0(0)$ & $1(16.7)$ & $3(50.0)$ & $7(50.0)$ & $11(36.7)$ & $2(50.0)$ \\
\hline Dry mouth & $0(0)$ & $3(50.0)$ & $2(33.3)$ & $5(33.3)$ & $10(33.3)$ & $2(50.0)$ \\
\hline Dry skin & $1(33.3)$ & $2(33.3)$ & $2(33.3)$ & $4(26.7)$ & $9(30.0)$ & $0(0)$ \\
\hline Nausea & $1(33.3)$ & $2(33.3)$ & $1(16.7)$ & $4(26.7)$ & $8(26.7)$ & $2(50.0)$ \\
\hline Detachment of retinal pigment epithelium & $0(0)$ & $0(0)$ & $0(0)$ & $7(50.0)$ & $7(23.3)$ & $1(25.0)$ \\
\hline Vomiting & $0(0)$ & $2(33.3)$ & $2(33.3)$ & $2(13.3)$ & $6(20.0)$ & $1(25.0)$ \\
\hline Malaise & $0(0)$ & $2(33.3)$ & $2(33.3)$ & $2(13.3)$ & $6(20.0)$ & $1(25.0)$ \\
\hline Decreased appetite & $1(33.3)$ & $1(16.7)$ & $1(16.7)$ & $2(13.3)$ & $6(20.0)$ & $2(50.0)$ \\
\hline Patients with CTCAE grade $\geq 3$ event, $\mathrm{n}(\%)$ & $0(0)$ & $3(50.0)$ & $0(0)$ & $0(0)$ & $3(10.0)$ & $3(75.0)$ \\
\hline Neutropenia & $0(0)$ & $2(33.3)$ & $0(0)$ & $0(0)$ & $2(6.7)$ & $1(25.0)$ \\
\hline Nausea & $0(0)$ & $2(33.3)$ & $0(0)$ & $0(0)$ & $2(6.7)$ & $0(0)$ \\
\hline Decreased appetite & $0(0)$ & $1(16.7)$ & $0(0)$ & $0(0)$ & $1(3.3)$ & $2(50.0)$ \\
\hline Stomatitis & $0(0)$ & $1(16.7)$ & $0(0)$ & $0(0)$ & $1(3.3)$ & $0(0)$ \\
\hline Pneumonia & $0(0)$ & $0(0)$ & $0(0)$ & $0(0)$ & $1(3.3)$ & $1(25.0)$ \\
\hline Increased alanine aminotransferase & $0(0)$ & $1(16.7)$ & $0(0)$ & $0(0)$ & $1(3.3)$ & $0(0)$ \\
\hline Decreased appetite & $0(0)$ & $1(16.7)$ & $0(0)$ & $0(0)$ & $1(3.3)$ & $0(0)$ \\
\hline Hypoglycaemia & $0(0)$ & $0(0)$ & $0(0)$ & $0(0)$ & $1(3.3)$ & $1(25.0)$ \\
\hline Patients with SAE grade $\geq 3$ event, $\mathrm{n}(\%)$ & $0(0)$ & $0(0)$ & $2(33.3)$ & $0(0)$ & $2(6.7)$ & $1(25.0)$ \\
\hline Nausea & $0(0)$ & $0(0)$ & $1(16.7)$ & $0(0)$ & $1(3.3)$ & $0(0)$ \\
\hline Stomatitis & $0(0)$ & $0(0)$ & $1(16.7)$ & $0(0)$ & $1(3.3)$ & $0(0)$ \\
\hline Decreased appetite & $0(0)$ & $0(0)$ & $1(16.7)$ & $0(0)$ & $1(3.3)$ & $1(25.0)$ \\
\hline
\end{tabular}

SAE serious adverse event 
in three (8.8\%). Three SAEs were experienced by two patients $(6.7 \%)$ in Part A and one patient $(25.0 \%)$ in Part B. All patients with SAEs required hospitalization. Only one SAE, decreased appetite and nausea, was deemed to be causally related to AZD4547 treatment (Part A; $80 \mathrm{mg}$ bid). Two further SAEs, stomatitis (Part A; $80 \mathrm{mg}$ bid) and decreased appetite (Part B; $80 \mathrm{mg}$ bid), were not considered to be causally related to treatment with AZD4547. One death occurred during the study period (160 mg qd) following disease progression; the study investigators concluded that this death was not causally related to AZD4547 treatment.

\section{Dose interruptions and reductions}

Nine patients (30.0\%) in Part A reported dose interruptions following AEs, and 13/30 patients (43.3\%) experienced dose reductions, of whom $12(40.0 \%)$ had reductions following AEs, most commonly detachment of retinal pigment epithelium or other retinal disorders, as well as hyperphosphataemia and dizziness. One patient (25.0\%) in Part B had a dose interruption as a result of an $\mathrm{AE}$ of decreased appetite, and two patients (50.0\%) had dose reductions after reporting AEs of retinal detachment, nausea, and hypoglycaemia. The mean actual treatment duration was 80.1 days in Part A and 36.0 days in Part B. The mean relative dose intensity was $87 \%$ in Part A and $83.5 \%$ in Part B.

\section{Dose discontinuation}

In Part A, 9/30 patients (30.0\%) had an AE leading to discontinuation of the study drug, and these AEs were considered causally related to the study drug by the investigator. None of the patients in Part B had AEs leading to discontinuation. Retinal events led to study-drug discontinuation in $7 / 34$ patients (20.5\%) and all patients recovered.

\section{Other safety observations}

Treatment-related increases in blood phosphate levels were observed in 11 patients (36.7\%) in Part A and two patients (50.0\%) in Part B, with median change in phosphate levels from baseline ranging from -0.16 to $0.79 \mathrm{mmol} / \mathrm{L}$ in the $80 \mathrm{mg}$ bid cohort (combined from Parts A and B) to -0.29 to $0.72 \mathrm{mmol} / \mathrm{L}$ in the $160 \mathrm{mg}$ qd cohort. Time to onset ranged from 9 to 24 days. All except one patient received treatment with fosrenol in accordance with the management guidelines for hyperphosphataemia and recovered. No clinically relevant changes in vital or physical signs were observed. One patient (120 mg bid) with a normal ECG at baseline experienced an abnormal ECG with AZD4547 treatment; however, this was not considered to be clinically relevant. Three patients experienced a decrease in left ventricular ejection fraction (LVEF) of $\geq 10$ percentage points and three patients experienced an absolute LVEF value of $<55 \%$; however, no patients were reported to have fulfilled both criteria simultaneously and, consequently, these changes were not considered to be clinically relevant. Grade 1 and 2 decreases in platelet counts were observed in $13 / 30$ patients (43.3\%), and only in the $160 \mathrm{mg} \mathrm{qd}$ cohort. All other clinical laboratory observations were comparable between dosing levels. A trend in mean-value increase for transaminases and blood creatinine was observed, which consisted mainly of a one-grade shift.

\section{Pharmacokinetics}

Following single dosing, AZD4547 plasma levels were quantifiable across all investigated dosing levels. The mean plasma concentration-time profiles for single and multiple dosing are shown in Fig. 2. A summary of PK parameters is given in Table 3. Median time to maximum plasma concentration $\left(t_{\max }\right)$ ranged from 2.9 to $4.0 \mathrm{~h}$ across the dose levels of 40 $160 \mathrm{mg}$. After reaching maximum plasma concentration $\left(\mathrm{C}_{\max }\right)$, AZD4547 concentrations declined biphasically, with a mean terminal half-life $\left(\mathrm{t}_{1 / 2 \lambda z} ; \pm\right.$ standard deviation [SD]) ranging from $22.4( \pm 7.21)$ to $33.5( \pm 7.49) \mathrm{h}$. The ratio of the area under the plasma concentration-time curve from time 0 to infinity (AUC) to that from time 0 to time of last measurable concentration $\left(\mathrm{AUC}_{0-\mathrm{t}}\right)$ was $>0.87$, indicating that the sampling scheme used had reliably captured the plasma concentration-time profiles. The percentage coefficient of variation (CV\%) values for $\mathrm{C}_{\max }$ and AUC were $54.0-142 \%$ and $53.3-$ $117 \%$, respectively, across the dosing levels. Dose-normalized $\mathrm{C}_{\max }$ and AUC values were $9.58-21.4 \mathrm{ng} / \mathrm{mL}$ and $0.61-$ $1.35 \mathrm{~h} \cdot \mathrm{ng} / \mathrm{mL}$, respectively, for the dosing levels tested. Mean $( \pm \mathrm{SD})$ oral clearance $(\mathrm{CL} / \mathrm{F})$ ranged from $57.8( \pm 27.3)$ to $116( \pm 77.0) \mathrm{L} / \mathrm{h}$ and was independent of dose across the dosing range of $80-160 \mathrm{mg}$.

AZD4547 plasma levels were quantifiable across all levels and time points for multiple dosing, and steady state (ss) was reached by day 8 . The $\mathrm{CV} \%$ range for $\mathrm{C}_{\mathrm{ss}, \max }$ was 23.0 $65.9 \%$, and the $\mathrm{CV} \%$ range for $\mathrm{AUC}_{\mathrm{ss}}$ was $10.5-61.0 \%$. Dose-normalized values for $\mathrm{C}_{\mathrm{ss}, \max }$ and $\mathrm{AUC}_{\mathrm{ss}}$ were 1.60 $3.41 \mathrm{ng} / \mathrm{mL}$ and $11.4-29.7 \mathrm{~h} \cdot \mathrm{ng} / \mathrm{mL}$ across the different multiple dosing levels. Median $\mathrm{t}_{\max }$ ranged from 2.9 to $4.0 \mathrm{~h}$ postdose, in line with the data from single dosing. Mean $( \pm \mathrm{SD})$ $\mathrm{CL}_{\mathrm{ss}} / \mathrm{F}$ ranged from $37.9( \pm 19.9)$ to $87.9( \pm 9.37) \mathrm{L} / \mathrm{h}$, which were lower than the $\mathrm{CL} / \mathrm{F}$ values for single doses. The mean $( \pm \mathrm{SD})$ accumulation ratio $\left(\mathrm{R}_{\mathrm{AC}}\right.$; ratio of multiple-dose $\mathrm{AUC}_{\mathrm{ss}}$ to single-dose $\left.\mathrm{AUC}_{0-12 \mathrm{~h}}\right)$ was $3.34( \pm 1.98), 4.87( \pm 2.42)$, and 5.34 ( \pm 5.43 ), respectively, for $40 \mathrm{mg}, 80 \mathrm{mg}$, and $120 \mathrm{mg}$ bid dosing. The mean $\left( \pm \mathrm{SD}\right.$ ) value of $\mathrm{R}_{\mathrm{AC}}$ (ratio of multiple-dose $\mathrm{AUC}_{\mathrm{ss}}$ to single-dose $\left.\mathrm{AUC}_{0-24 \mathrm{~h}}\right)$ for the $160 \mathrm{mg}$ qd cohort was $2.42( \pm 1.56)$. The mean $( \pm \mathrm{SD})$ values of temporal change (Tc; ratio of multiple-dose $\mathrm{AUC}_{\mathrm{ss}}$ to single-dose AUC) were $1.37( \pm 1.01), 1.75( \pm 0.86), 1.61( \pm 1.41)$ and $1.37( \pm 0.88)$, 
Fig. 2 Plasma concentrationtime profiles of AZD4547 after a single dosing and $\mathbf{b}$ multiple dosing. Geometric mean plasma concentrations are shown against time for the dosing levels $40 \mathrm{mg}$ bid, $80 \mathrm{mg}$ bid (combined from cohorts dosed at the $80 \mathrm{mg}$ bid level across both Parts A and B), $120 \mathrm{mg}$ bid, and $160 \mathrm{mg}$ qd a
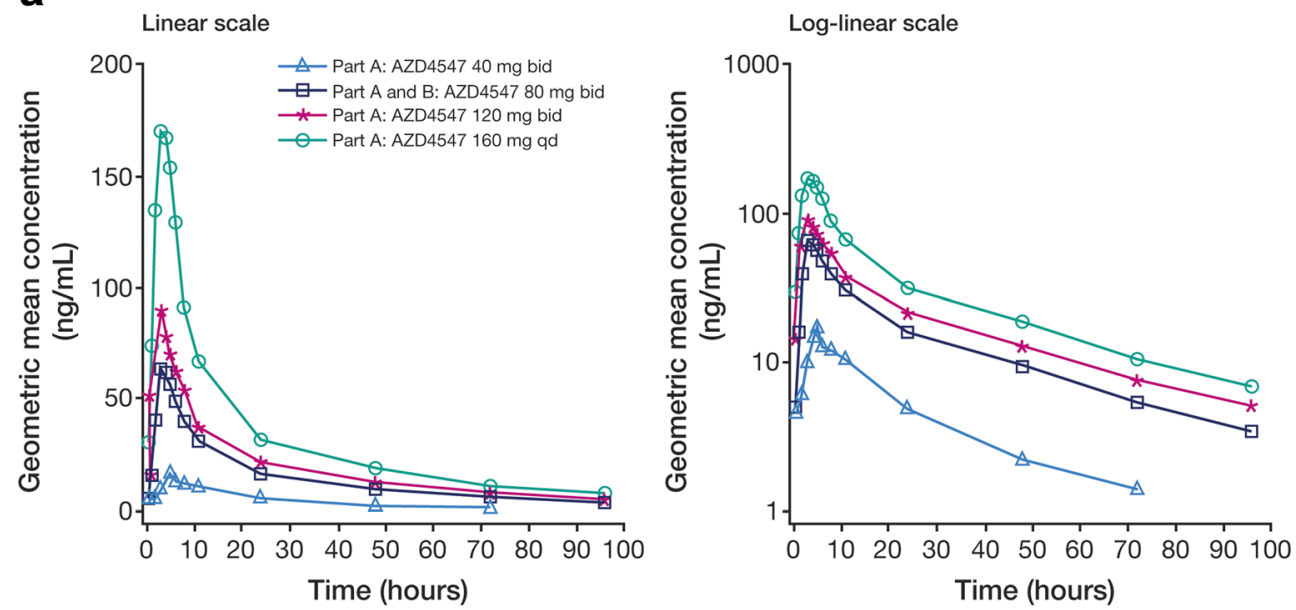

b

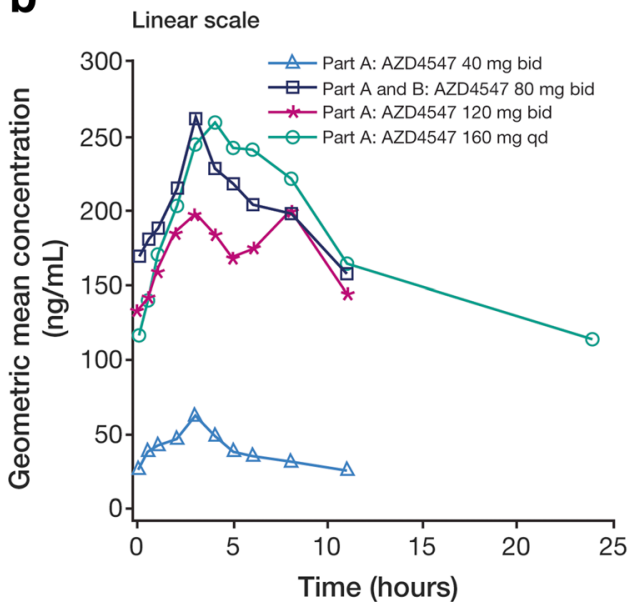

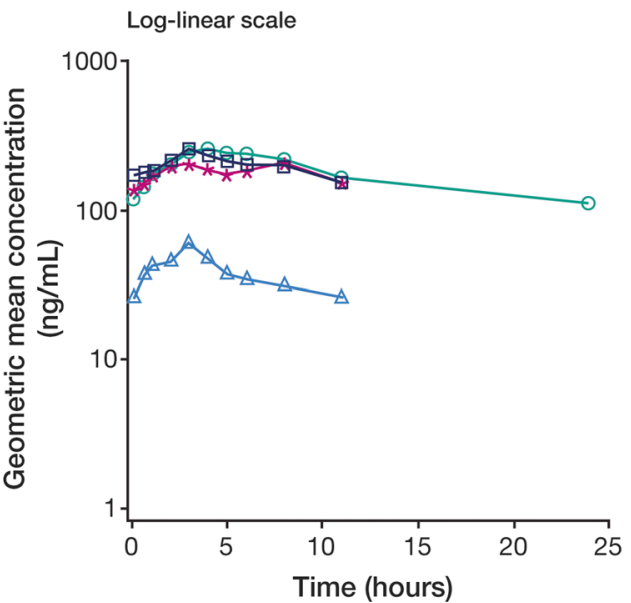

respectively, for $40 \mathrm{mg}, 80 \mathrm{mg}, 120 \mathrm{mg}$ bid and $160 \mathrm{mg}$ qd dosing.

Urinary PK data were available for 27 patients (25/30 patients in Part A; $2 / 4$ patients in Part B). The mean $( \pm \mathrm{SD})$ steady-state fraction of the AZD4547 dose excreted in urine (fe) was $3.92 \%( \pm 0.828 \%), 3.66 \%( \pm 1.25 \%), 4.13 \%$ $( \pm 1.68 \%)$ and $3.78 \%( \pm 2.48 \%)$ for $40 \mathrm{mg}, 80 \mathrm{mg}, 120 \mathrm{mg}$ bid and $160 \mathrm{mg}$ qd dosing, respectively, suggesting that urinary excretion of AZD4547 is dose independent. Mean $( \pm \mathrm{SD})$ steady-state renal clearance $\left(\mathrm{CL}_{\mathrm{R}}\right)$ values were variable at $3.23( \pm 0.58), 1.25( \pm 0.43), 2.32( \pm 0.63)$ and 1.38 $( \pm 0.59) \mathrm{L} / \mathrm{h}$, respectively, for $40 \mathrm{mg}, 80 \mathrm{mg}, 120 \mathrm{mg}$ bid and $160 \mathrm{mg}$ qd dosing, but showed no dose-dependency trend.

\section{Preliminary efficacy}

Complete responses and partial responses, according to RECIST v1.1, were not observed; however, stable disease ( $\geq 4$ weeks' duration) was observed in 21 patients $(70.0 \%$; $40 \mathrm{mg}$ bid, $n=3 ; 80 \mathrm{mg}$ bid, $n=3 ; 120 \mathrm{mg}$ bid, $n=5$; $160 \mathrm{mg} \mathrm{qd}, n=10)$ in Part A, with one patient $(25.0 \%$;
$80 \mathrm{mg}$ bid) continuing to experience stable disease at 10 weeks in Part B. Except for one patient in Part A with a nonevaluable response, all remaining patients showed disease progression. Post-baseline target lesion measurements were available in $25 / 30$ patients in Part A and all patients in Part $\mathrm{B}$; the median percentage change in the sum of the diameters was $5.9 \%$ (range $-6.8 \%$ to $48.9 \%$ ) in Part $\mathrm{A}$ and $3.0 \%$ (range $-16.3 \%$ to $23.4 \%$ ) in Part B.

\section{Discussion}

The FGFR pathway is involved in key cellular processes necessary for survival and differentiation. Accordingly, aberrant FGFR signalling has significant oncogenic potential. This Phase I study is the first to evaluate the safety and tolerability of AZD4547 in a population of Japanese patients with advanced solid malignancies for which no standard or effective treatment exists. The characteristics of this study population were comparable to those of the intended target population for AZD4547. 


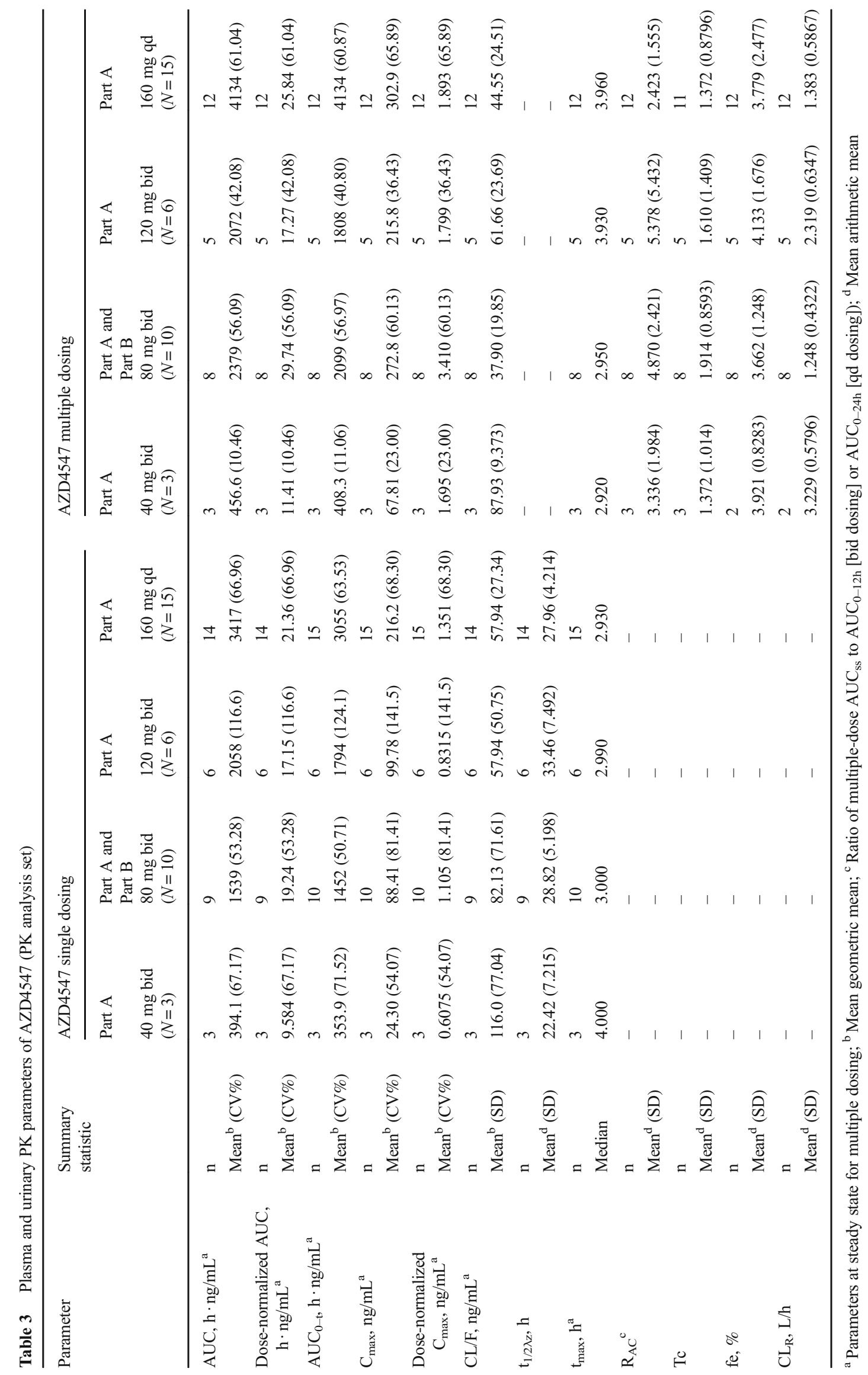




\section{Safety profile}

Overall, AEs during AZD4547 treatment were generally mild to moderate and reversible upon withdrawal of treatment, as has been observed previously [16]. No DLTs were observed in our study and the drug was not titrated to an MTD as a result of emerging safety data from the Phase I study conducted in Western patients [16]. In the study in Western patients, AZD4547-treatment-related DLTs of renal failure, elevated liver enzymes, hyperphosphataemia, and mucositis were observed at the dose range 20-200 $\mathrm{mg}$ bid [16]. The absence of causally related DLTs in our Japanese population may, therefore, be explained by the lower dosing levels, despite body mass in the Japanese patients being smaller than in the Western patients. An RD of $80 \mathrm{mg}$ bid was determined based on the combined safety data from our study and from the study in Western patients [16]; this RD was evaluated during the expansion phase.

Results of the expansion phase showed that the RD of $80 \mathrm{mg}$ bid was well tolerated in Japanese patients with FGFR-amplified tumours (as determined by FISH). Consistent with data from Western patients, the most common AEs in our study were gastrointestinal disorders, dryness, hyperphosphataemia, and eye disorders and included diarrhoea, stomatitis, dry mouth and skin, nausea, dysgeusia, and detachment of retinal pigment epithelium [16, 34, 35]. Similar safety findings have been reported for other selective FGFR receptors [36-38]. One of the safety concerns for selective FGFR inhibitors from preclinical toxicity studies has been hyperphosphataemia, caused by loss of FGF23 signalling, resulting in calcification of tissues [2, 32]. All phosphaterelated events in our study were of CTCAE grade $\leq 3$ and were controllable with therapeutic interventions. Taken together with available clinical data from AZD4547 and other FGFR inhibitors, this indicates that hyperphosphataemia with FGFR inhibitors is generally manageable in humans [16, 37].

\section{Pharmacokinetics}

The PK findings were generally consistent between AZD4547 single and multiple dosing. Following bid dosing in three cohorts (40 mg; $80 \mathrm{mg} ; 120 \mathrm{mg}$ ) and qd dosing in one cohort $(160 \mathrm{mg})$, steady state was achieved by day 8 , and the accumulation ratio was consistent with the prediction from singledose $t_{1 / 2 \lambda z}$. Dose-normalized PK parameters for single and multiple doses were similar across all dosing levels; however, the small number of patients in each cohort and the variability between plasma concentration-time plots make dose proportionality difficult to establish. Tc tended to be close to or slightly higher than unity, suggesting that there were no notable time-dependent changes in PK upon multiple dosing. A relatively small proportion of AZD4547 was excreted in the urine unchanged (3.8-4.1\% of the dose), suggesting that urinary excretion may be a minor route of AZD4547 elimination if AZD4547 absorption is good in humans. The results reported here are the first published PK data for AZD4547 in any patient population, and it would therefore be interesting to compare our PK findings with subsequent PK data that may emerge from the ongoing clinical development of AZD4547.

\section{Efficacy and comparisons with other FGFR inhibitors}

The best response following AZD4547 treatment in this study was stable disease for $\geq 4$ weeks in $70 \%$ of patients, with one $\mathrm{BC}$ patient experiencing stable disease at 10 weeks. Previous efficacy data from the Western population showed a best response of PR ( $80 \mathrm{mg}$ bid) for $\geq 12$ weeks in one patient with FGFR1-amplified squamous NSCLC [16]; stable disease was also observed in $4 / 21$ patients (19\%), three of whom (75\%) had confirmed FGFR amplification.

Efficacy data from clinical studies of other selective FGFR inhibitors have also been reported. In a Phase I study of BGJ398 (Novartis), PRs were observed in 2/17 evaluable patients with lung squamous cell carcinoma, with durations of 8 and 3 months [39]. It is important to note that this study population was selected on the basis of their FGFR amplification status. In an extended cohort of the same study, $8 / 25$ patients with previously treated advanced/metastatic urothelial carcinoma (UC) and FGFR3 alterations had PRs, with one unconfirmed complete response [40]. Published findings from a Phase I trial of the selective FGFR inhibitor JNJ-42756493 (Johnson \& Johnson) have shown PRs in 4/23 evaluable patients [36]. All patients demonstrating a PR had FGFR2 or FGFR3 translocations, and tumour types were reported as glioblastoma, UC, and endometrial cancer. Phase II studies of FGFR inhibitors are ongoing in different tumour types harbouring FGFR gene alterations. These include assessment of AZD4547 at the RD of $80 \mathrm{mg}$ bid in FGFR2-amplified GC and FGFR1-amplified BC (NCT01457846; NCT01795768) [35, 41], BGJ398 in patients with advanced FGFR-altered colangiocarcinoma [38], and JNJ-42756493 in patients with metastatic or unresectable UC with FGFR gene alterations [42]. Selective FGFR inhibitors may also have potential in combination with other agents $[43$, 44].

Further investigation is required to establish the treatment settings in which this new class of drugs can provide the most meaningful clinical benefit. The initial expectation was that selection of patients by screening for FGFR amplification may identify responsive patients; however, patients with FGFR gene amplification have responded inconsistently to FGFR inhibitors [16, 45]. A key focus for development of selective FGFR inhibitors will therefore be to determine how aberrations in FGFR may be predictive of a response to treatment and incorporate appropriate predictive biomarkers into patient stratification. Taking this into consideration, the ongoing Phase Ib BISCAY biomarker-directed multidrug umbrella 
study (NCT02546661) will allocate patients to AZD4547 treatment based on FGFR3 mutations or FGFR1-3 fusions [46].

Several non-selective, multi-targeted TKIs have been licensed that can act as FGFR inhibitors, including pazopanib, lenvatinib, ponatinib, regorafenib, and nintedanib. In addition to FGFRs, these compounds have activity against a wide range of targets, including VEGFR1-3 and platelet-derived growth factor $[47,48]$, and have demonstrated clinical benefit for the treatment of several tumour types, such as renal cell carcinoma [23, 24], soft tissue sarcoma [49, 50], thyroid cancer [51], metastatic colorectal cancer [52], chronic myeloid leukaemia [53] and NSCLC [54, 55]. However, cardiac toxicity has been reported as a widespread AE with multi-targeted TKIs and is thought to be a dose-dependent, on-target effect related to the inhibition of VEGFR [56]. It is therefore useful to note that no significant cardiac toxicity was reported with AZD4547 treatment during this study, and cardiac toxicity has not been highlighted as a concern from previous studies with selective FGFR inhibitors [16, 35, 37, 39].

\section{Summary}

AZD4547 was well tolerated in this Phase I study and no DLTs were reported. Based on safety data from Part A, and taking into account previous data in Western patients [16], the recommended dose was determined as $80 \mathrm{mg}$ bid. Further investigation is required to establish the treatment settings in which this new class of drugs can provide the most meaningful clinical benefit.

Acknowledgments We would like to thank the staff and investigators at all three study sites. We thank Lizzie Wilkins $\mathrm{PhD}$ from Mudskipper Business Ltd, who provided medical writing assistance funded by AstraZeneca.

\section{Compliance with ethical standards}

Conflict of interest HS has received research funding from AstraZeneca, Daiichi Sankyo, Ono Pharmaceutical, Eli Lilly Japan, Bayer Yakuhin, Taiho Pharmaceutical, MSD, Linical, Bristol-Myers Squibb, and Sanofi. CK has received research funding from AstraZeneca and Maruishi Pharmaceutical. YK, YT, KF, TS, and NT have received research funding from AstraZeneca. SI has received research funding from AstraZeneca and honoraria from Chugai Pharmaceutical, Taiho Pharmaceutical, and Eli Lilly Japan. TF is an employee of AstraZeneca. CT and DL are employees of AstraZeneca and own AstraZeneca stock. YY has received research funding from AstraZeneca, Novartis Pharma, and Daiichi Sankyo and honoraria from Chugai Pharmaceutical, Taiho Pharmaceutical, and Yakult Pharmaceutical Industry.

Funding This study was funded by AstraZeneca.

Ethical approval All procedures performed in studies involving human participants were in accordance with the ethical standards of the institutional and/or national research committee and with the 1964
Helsinki declaration and its later amendments or comparable ethical standards.

Informed consent Informed consent was obtained from all individual participants included in the study.

Open Access This article is distributed under the terms of the Creative Commons Attribution 4.0 International License (http:// creativecommons.org/licenses/by/4.0/), which permits unrestricted use, distribution, and reproduction in any medium, provided you give appropriate credit to the original author(s) and the source, provide a link to the Creative Commons license, and indicate if changes were made.

\section{References}

1. Eswarakumar VP, Lax I, Schlessinger J (2005) Cellular signaling by fibroblast growth factor receptors. Cytokine Growth Factor Rev 16:139-149

2. Turner N, Grose R (2010) Fibroblast growth factor signalling: from development to cancer. Nat Rev Cancer 10:116-129

3. Thisse B, Thisse C (2005) Functions and regulations of fibroblast growth factor signaling during embryonic development. Dev Biol 287:390-402

4. Weinstein IB, Joe AK (2006) Mechanisms of disease: oncogene addiction - a rationale for molecular targeting in cancer therapy. Nat Clin Pract Oncol 3:448-457

5. Cappellen D, de Oliveira C, Ricol D, de Medina S, Bourdin J, Sastre-Garau X, Chopin D, Thiery JP, Radvanyi F (1999) Frequent activating mutations of FGFR3 in human bladder and cervix carcinomas. Nat Genet 23:18-20

6. Dutt A, Salvesen HB, Chen TH, Ramos AH, Onofrio RC, Hatton C, Nicoletti R, Winckler W, Grewal R, Hanna M, Wyhs N, Ziaugra L, Richter DJ, Trovik J, Engelsen IB, Stefansson IM, Fennell T, Cibulskis K, Zody MC, Akslen LA, Gabriel S, Wong KK, Sellers WR, Meyerson M, Greulich H (2008) Drug-sensitive FGFR2 mutations in endometrial carcinoma. Proc Natl Acad Sci U S A 105:8713-8717

7. Taylor JG, Cheuk AT, Tsang PS, Chung JY, Song YK, Desai K, Yu Y, Chen QR, Shah K, Youngblood V, Fang J, Kim SY, Yeung C, Helman LJ, Mendoza A, Ngo V, Staudt LM, Wei JS, Khanna C, Catchpoole D, Qualman SJ, Hewitt SM, Merlino G, Chanock SJ, Khan J (2009) Identification of FGFR4-activating mutations in human rhabdomyosarcomas that promote metastasis in xenotransplanted models. J Clin Invest 119:3395-3407

8. Hammerman P, Sivachenko A, Pho N, Cherniak A, Ramos A, Getz G, Meyerson M (2011) Genomic characterization and targeted therapeutics in squamous cell lung cancer. 14th World Conference on Lung Cancer. Amsterdam, The Netherlands, 3-7 July:abst 1161

9. Courjal F, Cuny M, Simony-Lafontaine J, Louason G, Speiser P, Zeillinger R, Rodriguez C, Theillet C (1997) Mapping of DNA amplifications at 15 chromosomal localizations in 1875 breast tumors: definition of phenotypic groups. Cancer Res 57:4360-4367

10. Holzmann K, Grunt T, Heinzle C, Sampl S, Steinhoff H, Reichmann N, Kleiter M, Hauck M, Marian B (2012) Alternative splicing of fibroblast growth factor receptor IgIII loops in cancer. J Nucleic Acids 2012: 950508

11. Gavine PR, Mooney L, Kilgour E, Thomas AP, Al-Kadhimi K, Beck S, Rooney C, Coleman T, Baker D, Mellor MJ, Brooks AN, Klinowska T (2012) AZD4547: an orally bioavailable, potent, and selective inhibitor of the fibroblast growth factor receptor tyrosine kinase family. Cancer Res 72:2045-2056 
12. Xie L, Su X, Zhang L, Yin X, Tang L, Zhang X, Xu Y, Gao Z, Liu K, Zhou M, Gao B, Shen D, Zhang LH, Ji JF, Gavine PR, Zhang J, Kilgour E, Zhang X, Ji Q (2013) FGFR2 gene amplification in gastric cancer predicts sensitivity to the selective FGFR inhibitor AZD4547. Clin Cancer Res 19:2572-2583

13. Zhang J, Zhang L, Su X, Li M, Xie L, Malchers F, Fan S, Yin X, Xu Y, Liu K, Dong Z, Zhu G, Qian Z, Tang L, Zhan P, Ji Q, Kilgour E, Smith PD, Brooks AN, Thomas RK, Gavine PR (2012) Translating the therapeutic potential of AZD4547 in FGFR1-amplified nonsmall cell lung cancer through the use of patient-derived tumor xenograft models. Clin Cancer Res 18:6658-6667

14. Chang J, Wang S, Zhang Z, Liu X, Wu Z, Geng R, Ge X, Dai C, Liu R, Zhang Q, Li W, Li J (2015) Multiple receptor tyrosine kinase activation attenuates therapeutic efficacy of the fibroblast growth factor receptor 2 inhibitor AZD4547 in FGFR2 amplified gastric cancer. Oncotarget 6:2009-2022

15. Yao TJ, Zhu JH, Peng DF, Cui Z, Zhang C, Lu PH (2015) AZD4547 exerts potent cytostatic and cytotoxic activities against fibroblast growth factor receptor (FGFR)-expressing colorectal cancer cells. Tumour Biol 36:5641-5648

16. Andre F, Ranson M, Dean E, Varga A, van der Noll R, Stockman PK, Ghiorghiu D, Kilgour E, Smith PD, Macpherson M, Lawrence P, Hastie A, Schellens JH (2013) Results of a phase I study of AZD4547, an inhibitor of fibroblast growth factor receptor (FGFR), in patients with advanced solid tumours. Cancer Res 73(8 Suppl):abst LB-145

17. Motzer RJ, Hutson TE, Tomczak P, Michaelson MD, Bukowski RM, Oudard S, Negrier S, Szczylik C, Pili R, Bjarnason GA, Garcia-delMuro X, Sosman JA, Solska E, Wilding G, Thompson JA, Kim ST, Chen I, Huang X, Figlin RA (2009) Overall survival and updated results for sunitinib compared with interferon alfa in patients with metastatic renal cell carcinoma. J Clin Oncol 27:3584-3590

18. Motzer RJ, Hutson TE, Tomczak P, Michaelson MD, Bukowski RM, Rixe O, Oudard S, Negrier S, Szczylik C, Kim ST, Chen I, Bycott PW, Baum CM, Figlin RA (2007) Sunitinib versus interferon alfa in metastatic renal-cell carcinoma. N Engl J Med 356:115-124

19. Cheng AL, Kang YK, Chen Z, Tsao CJ, Qin S, Kim JS, Luo R, Feng J, Ye S, Yang TS, Xu J, Sun Y, Liang H, Liu J, Wang J, Tak WY, Pan H, Burock K, Zou J, Voliotis D, Guan Z (2009) Efficacy and safety of sorafenib in patients in the Asia-Pacific region with advanced hepatocellular carcinoma: a phase III randomised, double-blind, placebo-controlled trial. Lancet Oncol 10:25-34

20. Escudier B, Szczylik C, Eisen T, Stadler WM, Schwartz B, Shan M, Bukowski RM (2005) Randomized Phase III trial of the Raf kinase and VEGFR inhibitor sorafenib (BAY 43-9006) in patients with advanced renal cell carcinoma (RCC). J Clin Oncol 23(16S):abst 4510

21. Escudier B, Eisen T, Stadler WM, Szczylik C, Oudard S, Staehler M, Negrier S, Chevreau C, Desai AA, Rolland F, Demkow T, Hutson TE, Gore M, Anderson S, Hofilena G, Shan M, Pena C, Lathia C, Bukowski RM (2009) Sorafenib for treatment of renal cell carcinoma: final efficacy and safety results of the phase III treatment approaches in renal cancer global evaluation trial. J Clin Oncol 27:3312-3318

22. Llovet JM, Ricci S, Mazzaferro V, Hilgard P, Gane E, Blanc JF, de Oliveira AC, Santoro A, Raoul JL, Forner A, Schwartz M, Porta C, Zeuzem S, Bolondi L, Greten TF, Galle PR, Seitz JF, Borbath I, Haussinger D, Giannaris T, Shan M, Moscovici M, Voliotis D, Bruix J (2008) Sorafenib in advanced hepatocellular carcinoma. N Engl J Med 359:378-390

23. Sternberg CN, Hawkins RE, Wagstaff J, Salman P, Mardiak J, Barrios CH, Zarba JJ, Gladkov OA, Lee E, Szczylik C, McCann L, Rubin SD, Chen M, Davis ID (2013) A randomised, doubleblind phase III study of pazopanib in patients with advanced and/ or metastatic renal cell carcinoma: final overall survival results and safety update. Eur J Cancer 49:1287-1296

24. Sternberg CN, Davis ID, Mardiak J, Szczylik C, Lee E, Wagstaff J, Barrios CH, Salman P, Gladkov OA, Kavina A, Zarba JJ, Chen M,
McCann L, Pandite L, Roychowdhury DF, Hawkins RE (2010) Pazopanib in locally advanced or metastatic renal cell carcinoma: results of a randomized phase III trial. J Clin Oncol 28:1061-1068

25. Batchelor T, Mulholland P, Neyns B, Nabors LB, Campone M, Wick A, Mason W, Xu J, Liu Q, van den Bent M (2010) A Phase III randomized study comparing the efficacy of cediranib as monotherapy, and in combination with lomustine, with lomustine alone in recurrent glioblastoma patients. Ann Oncol 21(Suppl 8):viii4 (abst LBA7)

26. Ledermann JA, Perren TJ, Raja FA, Embleton A, Rustin GJS, Jayson G, Kaye SB, Swart AM, Vaughan M, Hirte H, on behalf of the ICON6 Collaborators (2013) Randomised double-blind phase III trial of cediranib (AZD 2171) in relapsed platinum sensitive ovarian cancer: results of the ICON6 trial. Eur J Cancer 49(Suppl 3):abst LBA 10

27. Robertson JD, Botwood NA, Rothenberg ML, Schmoll H-J (2009) Phase III trial of FOLFOX plus bevacizumab or cediranib (AZD2171) as first-line treatment of patients with metastatic colorectal cancer: HORIZON III. Clin Colorectal Cancer 8:59-60

28. Vasudev NS, Reynolds AR (2014) Anti-angiogenic therapy for cancer: current progress, unresolved questions and future directions. Angiogenesis 17:471-494

29. Casanovas O, Hicklin DJ, Bergers G, Hanahan D (2005) Drug resistance by evasion of antiangiogenic targeting of VEGF signaling in late-stage pancreatic islet tumors. Cancer Cell 8:299-309

30. Kopetz S, Hoff PM, Morris JS, Wolff RA, Eng C, Glover KY, Adinin R, Overman MJ, Valero V, Wen S, Lieu C, Yan S, Tran HT, Ellis LM, Abbruzzese JL, Heymach JV (2010) Phase II trial of infusional fluorouracil, irinotecan, and bevacizumab for metastatic colorectal cancer: efficacy and circulating angiogenic biomarkers associated with therapeutic resistance. J Clin Oncol 28:453-459

31. Batchelor TT, Sorensen G, di Tomaso E, Duda DG, Zhang W-T, Ancukiewicz M, Lahdenranta J, Louis D, Plotkin S, Ivy P, Loeffler JS, Wen P, Jain RK (2008) A multidisciplinary phase II study of AZD2171 (cediranib), an oral pan-VEGF receptor tyrosine kinase inhibitor, in patients with recurrent glioblastoma. Proc Am Assoc Cancer Res 49:abst LB-247

32. Brown AP, Courtney CL, King LM, Groom SC, Graziano MJ (2005) Cartilage dysplasia and tissue mineralization in the rat following administration of a FGF receptor tyrosine kinase inhibitor. Toxicol Pathol 33:449-455

33. Skolnik JM, Barrett JS, Jayaraman B, Patel D, Adamson PC (2008) Shortening the timeline of pediatric phase I trials: the rolling six design. J Clin Oncol 26:190-195

34. Arkenau HT, Saggese M, Hollebecque A, Mathewson A, Lemech CR, Landers D, Frewer P, Kilgour E, Brooks N (2014) A phase 1 expansion cohort of the fibroblast growth factor receptor (FGFR) inhibitor AZD4547 in patients (pts) with advanced gastric (GC) and gastroesophageal (GOJ) cancer. J Clin Oncol 32(15S):abst 2620

35. Bang Y-J, Van Cutsem E, Mansoor W, Petty RD, Chao Y, Cunningham D, Ferry D, Landers D, Stockman P, Smith NR, Geh C, Kilgour E (2015) A randomized, open-label phase II study of AZD4547 (AZD) versus paclitaxel (P) in previously treated patients with advanced gastric cancer (AGC) with fibroblast growth factor receptor 2 (FGFR2) polysomy or gene amplification (amp): SHINE study. J Clin Oncol 33(15S):abst 4014

36. Tabernero J, Bahleda R, Dienstmann R, Infante JR, Mita A, Italiano A, Calvo E, Moreno V, Adamo B, Gazzah A, Zhong B, Platero SJ, Smit JW, Stuyckens K, Chatterjee-Kishore M, Rodon J, Peddareddigari V, Luo FR, Soria JC (2015) Phase I dose-escalation study of JNJ42756493, an oral pan-fibroblast growth factor receptor inhibitor, in patients with advanced solid tumors. J Clin Oncol 33:3401-3408

37. Sequist LV, Cassier P, Varga A, Tabernero J, Schellens JH, Delord JP, LoRusso P, Camidge DR, Hidalgo Medina M, Schuler M, Campone M, Tian GG, Wong S, Corral J, Isaacs R, Sen SK, Graus Porta D, Kulkarni SG, Lefebvre C, Wolf J (2014) Phase I study of BGJ398, a selective pan-FGFR inhibitor in genetically 
preselected advanced solid tumors. Cancer Res 74(19 Suppl):abst CT326

38. Javle MM, Shroff RT, Zhu A, Sadeghi S, Choo SP, Borad MJ, Lowery MA, El-Khoueiry A, Macarulla T, Philip PA, Oh D-Y, Van Cutsem E, Yeh K-H, Isaacs R, McGarry C, Sen S, BekaiiSaab TS (2016) A phase 2 study of BGJ398 in patients (pts) with advanced or metastatic FGFR-altered cholangiocarcinoma (CCA) who failed or are intolerant to platinum-based chemotherapy. J Clin Oncol 34:abstr 335

39. Nogova L, Sequist LV, Cassier PA, Hidalgo M, Delord JP, Schuler MH, Lim WT, Camidge DR, Buettner R, Heukamp LC, Gardizi M, Scheffler M, Kambartel K, Ringeisen FP, Sen S, Isaacs R, Joannaert M, Lefebvre C, Wolf J (2014) Targeting FGFR1-amplified lung squamous cell carcinoma with the selective pan-FGFR inhibitor BGJ398. J Clin Oncol 32(15S):abst 8034

40. Pal SK, Rosenberg JE, Keam B, Wolf J, Berger R, Dittrich C, Hoffman-Censits JH, Quinn D, van der Noll R, Burris HA, Galsky MD, Gravis G, Lee J-L, Medioni J, Mortazavi A, Maroto P, Parker K, Chen X, Isaacs R, Bajorin DF (2016) Efficacy of BGJ398, a fibroblast growth factor receptor (FGFR) 1-3 inhibitor, in patients (pts) with previously treated advanced/metastatic urothelial carcinoma (mUC) with FGFR3 alterations. J Clin Oncol 34(Suppl):abst 4517

41. Smyth EC, Turner NC, Peckitt C, Pearson A, Brown G, Chua S, Gillbanks A, Johnston SR, Tarazona N, Cutts R, Kilgour E, Rooney C, Smith NR, Sumpter KA, Ajaz MA, Thomas AL, Watkins D, Chau I, Popat S, Cunningham D (2015) Phase II multicenter proof of concept study of AZD4547 in FGFR amplified tumours. J Clin Oncol 33(15S):abst 2508

42. Siefker-Radtke AO, Mellado B, Decaestecker K, Burke JM, O'Hagan A, Avadhani AN, Zhong B, Santiago-Walker AE, De Porre P, Brookman-May S, Garcia-Donas J (2016) A phase 2 study of JNJ-42756493, a pan-FGFR tyrosine kinase inhibitor, in patients (pts) with metastatic or unresectable urothelial cancer (UC) harboring FGFR gene alterations. J Clin Oncol 34(Suppl):abst TPS4575

43. Hyman DM, Tran B, Jaime JC, Garralda E, Machiels J-PH, Schellens JHM, Bedard P, Campone M, Cassier P, Sarantopoulos J, Vaishampayan UN, Chugh R, Mahipal A, Lockhart AC, Sessa C, Zander T, Ng M, Curigliano G, Bendiske J, Perez-Garcia JG (2016) Phase Ib study of BGJ398 in combination with BYL719 in patients (pts) with select advanced solid tumors. J Clin Oncol 34(Suppl): abst 2500

44. Jones RH, Anthoney DA, Jones RJ, Crabb SJ, Hussain SA, Birtle AJ, Spiliopoulou P, Robinson T, Knowles M, McLellan L, Jones H, Boylan Z, Landers D, Atuah K, Sherratt D, Brown SR, Flanagan L, Loadman P, Twelves C, Chester JD (2016) FIESTA: a Phase Ib and pharmacokinetic trial of AZD4547 in combination with gemcitabine and cisplatin. J Clin Oncol 34(Suppl):abst 4521

45. Pearson A, Smyth E, Babina IS, Herrera-Abreu MT, Tarazona N, Peckitt C, Kilgour E, Smith NR, Geh C, Rooney C, Cutts R, Campbell J, Ning J, Fenwick K, Swain A, Brown G, Chua S, Thomas A, Johnston SR, Ajaz M, Sumpter K, Gillbanks A, Watkins D, Chau I, Popat S, Cunningham D, Turner NC (2016) High-level clonal FGFR amplification and response to FGFR inhibition in a translational clinical trial. Cancer Discov 6:838-851

46. Powles T, Kilgour E, Mather R, Galer A, Arkenau H-T, Farnsworth A, Wilde J, Ratnayake J, Landers D (2016) BISCAY, a phase Ib, biomarker-directed multidrug umbrella study in patients with metastatic bladder cancer. J Clin Oncol 34(Suppl):abst TPS4577
47. Helsten T, Schwaederle M, Kurzrock R (2015) Fibroblast growth factor receptor signaling in hereditary and neoplastic disease: biologic and clinical implications. Cancer Metastasis Rev 34:479-496

48. Lewin J, Siu LL (2015) Development of fibroblast growth factor receptor inhibitors: kissing frogs to find a prince? J Clin Oncol 33: $3372-3374$

49. van Der Graaf WT, Blay JY, Chawla SP, Kim DW, Bui-Nguyen B, Casali PG, Schoffski P, Aglietta M, Staddon AP, Beppu Y, Le Cesne A, Gelderblom H, Judson IR, Araki N, Ouali M, Marreaud S, Hodge R, Dewji MR, Coens C, Demetri GD, Fletcher CD, Dei Tos AP, Hohenberger P (2012) Pazopanib for metastatic softtissue sarcoma (PALETTE): a randomised, double-blind, placebocontrolled phase 3 trial. Lancet 379:1879-1886

50. Sleijfer S, Ray-Coquard I, Papai Z, Le Cesne A, Scurr M, Schoffski P, Collin F, Pandite L, Marreaud S, De Brauwer A, Van Glabbeke M, Verweij J, Blay JY (2009) Pazopanib, a multikinase angiogenesis inhibitor, in patients with relapsed or refractory advanced soft tissue sarcoma: a phase II study from the European organisation for research and treatment of cancer-soft tissue and bone sarcoma group (EORTC study 62043). J Clin Oncol 27:3126-3132

51. Schlumberger M, Tahara M, Wirth LJ, Robinson B, Brose MS, Elisei R, Habra MA, Newbold K, Shah MH, Hoff AO, Gianoukakis AG, Kiyota N, Taylor MH, Kim SB, Krzyzanowska MK, Dutcus CE, de las Heras B, Zhu J, Sherman SI (2015) Lenvatinib versus placebo in radioiodine-refractory thyroid cancer. N Engl J Med 372:621-630

52. Grothey A, Van Cutsem E, Sobrero A, Siena S, Falcone A, Ychou M, Humblet Y, Bouche O, Mineur L, Barone C, Adenis A, Tabernero J, Yoshino T, Lenz HJ, Goldberg RM, Sargent DJ, Cihon F, Cupit L, Wagner A, Laurent D (2013) Regorafenib monotherapy for previously treated metastatic colorectal cancer (CORRECT): an international, multicentre, randomised, placebocontrolled, phase 3 trial. Lancet 381:303-312

53. Cortes JE, Kim DW, Pinilla-Ibarz J, le Coutre P, Paquette R, Chuah C, Nicolini FE, Apperley JF, Khoury HJ, Talpaz M, Dipersio J, DeAngelo DJ, Abruzzese E, Rea D, Baccarani M, Muller MC, Gambacorti-Passerini C, Wong S, Lustgarten S, Rivera VM, Clackson T, Turner CD, Haluska FG, Guilhot F, Deininger MW, Hochhaus A, Hughes T, Goldman JM, Shah NP, Kantarjian H (2013) A phase 2 trial of ponatinib in Philadelphia chromosomepositive leukemias. N Engl J Med 369:1783-1796

54. du Bois A, Kristensen G, Ray-Coquard I, Reuss A, Pignata S, Colombo N, Denison U, Vergote I, Del Campo JM, Ottevanger P, Heubner M, Minarik T, Sevin E, de Gregorio N, Bidzinski M, Pfisterer J, Malander S, Hilpert F, Mirza MR, Scambia G, Meier W, Nicoletto MO, Bjorge L, Lortholary A, Sailer MO, Merger M, Harter P (2016) Standard first-line chemotherapy with or without nintedanib for advanced ovarian cancer (AGO-OVAR 12): a randomised, double-blind, placebo-controlled phase 3 trial. Lancet Oncol 17:78-89

55. Reck M, Kaiser R, Mellemgaard A, Douillard JY, Orlov S, Krzakowski M, von Pawel J, Gottfried M, Bondarenko I, Liao M, Gann CN, Barrueco J, Gaschler-Markefski B, Novello S (2014) Docetaxel plus nintedanib versus docetaxel plus placebo in patients with previously treated non-small-cell lung cancer (LUME-Lung 1): a phase 3, double-blind, randomised controlled trial. Lancet Oncol 15:143-155

56. Escudier B, Grünwald V, Ravaud A, Ou YC, Castellano D, Lin CC, Gschwend JE, Harzstark A, Beall S, Pirotta N, Squires M, Shi M, Angevin E (2014) Phase II results of dovitinib (TKI258) in patients with metastatic renal cell cancer. Clin Cancer Res 20:3012-3022 